\title{
LEGAL PROTECTION AND RESOLUTION OF BREACH IN TRADE SECRET
}

\author{
Riki Andus Manulang \\ $185100060 P$ \\ Fakultas Komputer, 448757210 \\ rikiandusmanulang.student@umitra.ac.id
}

\begin{abstract}
As a developing country, Indonesia needs to strive for strong competition among the business community. This is in line with global conditions in the field of trade and investment. Such competitiveness has long been known in the Intellectual Property Rights (HAKI) system.

The era of globalization, this is arguably one of the causes of intellectual property rights violations (IPR). Like a time bomb that can explode at any time and the explosion effect can be on everything around it. Progress in all sectors, especially in the fields of industry and trade, is one of the victims of globalization. The higher industrialization flows and trade flows demanded the accuracy and speed of transactions are in part. And of course there are many problems that arise in it, because in every positive case there is a negative side. For example, in the case of "Music Industry" (Music Industry), especially in the cassette / DVD / VCD trade, sometimes people who are positioned as consumers prefer prices that are relatively cheap rather than expensive. Although of course the expensive ones have higher quality.

Some time ago, precisely in July 2012 as quoted in the sitejogja.okezone.com The Government through the Directorate of Investigation of the Directorate General of Intellectual Property Rights of the Ministry of Law and Human Rights (HAM) handled 44 cases of intellectual property rights violations (HKI) per May 2012. The 44 cases are related to the IPR domain, namely cases of copyright, patent, brand, industrial design, and Trade Secrets violations. And according to the Investigation Director of the Ministry of Law and Human Rights, Mohammad Adri, said, of the 44 cases of violations of IPR, the most cases were cases of brand violations which reached 27 cases. The second most, cases of industrial design violations ( 7 cases) and copyright cases ( 4 cases). The remaining patent cases and trade secrets. Illegal or pirated computer software problems are found in copyright cases.
\end{abstract}

Keywords: HakI, Trade. 


\section{A. INTRODUCTION}

\section{1) Definition of Trade Secrets}

According to Law No. 30 of 2000 concerning Trade Secrets (UURD), specifically article 1 point 1 states that "Trade Secrets are information that is not known to the public in the field of technology and / or business, has economic value because it is useful in business activities, and is kept confidential by the secret owner Trade. "Whereas the meaning of Trade Secret is the right to a Trade Secret arising under the Trade Secret Law.

Based on the above understanding, we can see that Trade Secrets is very valuable information for the company, because it must be kept confidential. The value of this information is because the information can bring economic benefits to the company.

\section{Difference between "Trade Secrets" and Intellectual Property Rights (HAKI)}

There are 3 main differences between Trade Secrets and other forms of IPR such as copyrights, patents and brands. The three differences can be described as follows :

a) Other forms of IPR are not confidential. Other forms of intellectual property rights are protected because they are a kind of wealth owned by others. Indeed, unless information about an invention is disclosed, patent protection cannot be obtained from the state. If works that are copyrighted or a brand are not used in general, then there is no commercial value. Trade secrets are protected because their secret nature causes the information to be valuable. Trade secrets consist of information that is only of commercial value if the confidentiality is not lost.

b) Trade Secret gets protection even though it does not contain the value of creativity or new thinking. What is important is that the Trade Secret is not generally known. For example, an effective work system, perhaps not so creative, but its effectiveness and confidentiality causes information to be of commercial value.

c) The other forms of IPR are always in the form of certain forms that can be written, drawn or recorded exactly in accordance with the registration requirements stipulated by government agencies. Trade Secrets should not be written. The important thing is not the exact form of writing or recording of information, but the use of concepts, ideas or information that can be given to other parties verbally. This is different from patents or brands.

Although there are differences between Trade Secrets and other forms of IPR, from these differences it turns out there are still overlapping relationships. This overlapping relationship is very clear in terms of patents. If a company has an invention, they can choose between maintaining the secrecy of the principle underlying the invention or patenting the invention. If the company chooses to maintain the confidentiality of its 
findings, the information is protected by law as long as its confidentiality is not lost. Conversely, if the company chooses to patent its invention, the nature of its confidentiality is lost, but the company obtains patent protection for a limited period of time. During the expiration of the patent, the protection for the invention was also lost. However, holders of patent rights are given a guarantee of protection for a limited validity period, protection from the Trade Secret law also carries the risk that the rights will be lost in line with the loss of the confidentiality of the information.

However, for inventions that are easily dismantled or analyzed and reproduced, patent protection is a safer type of protection, even though there is a limited protection period. Of course this is not a problem, when the invention step can be carried out continuously on the patent so that when that right will expire a new patent can be requested.

The subject of the right to the Trade Secret is the owner of the secret itself. The Trade Secret Owner can use and utilize the Trade Secret or prevent other parties from using it. However, as with other types of intellectual property rights, the owner may also license another party to use the Trade Secret for a certain period of time, through a license agreement. License agreements create obligations for the licensee to maintain confidentiality.

\section{What is the legal protection of the Trade Secret and its settlement if there is a violation of the Trade Secret}

The need for legal protection against trade secrets is also in accordance with one of the provisions in the Agreement on Trade Related Aspects of Intellectual Property Rights (TRIPs Agreement) which is an attachment of the Agreement Establishing the World Trade Organization on Trade Organizations, as already ratified by Indonesia with Law No. 7 of 1994. The existence of such protection will encourage the birth of new findings or inventions which, although treated confidentially, still receive legal protection, both in terms of ownership, control, and utilization by the inventor. To manage the Trade Secret administration, the government is currently appointing the Ministry of Justice and Human Rights c.q. Directorate General of Intellectual Property Rights to do services in the field of Intellectual Property Rights.

Trade Secret Law No. 30 of 2000 provides the scope of trade secret protection, which includes production methods, processing methods, sales methods, or other information in the field of technology and / or business that has economic value and is not known by the general public.

A Trade Secret will get protection if the information is actually confidential, has economic value, and is kept confidential through appropriate efforts.

- It is confidential, meaning that the information is only known by certain parties or is not generally known by the public.

Having economic value, it means that the confidentiality of this information can be used to carry out business activities that are commercial in nature or can increase profits economically. Information is considered to be kept confidential if the owner or the parties 
who control it have taken appropriate and appropriate steps.

In the realm of IPR, basically the protection is based on the recognition of the right to wealth and the right to enjoy that wealth within a certain time. This means that during certain times the owner or right holder of IPR can allow or prohibit to know or disseminate information (Trade Secrets).

Violation of Trade Secrets occurs when a person intentionally discloses a Trade Secret, denies an agreement or denies written or unwritten obligations to safeguard the relevant Trade Secret. To overcome the violation, legal protection is needed for the owner and / or holder of the IPR concerned.

If someone feels the other party has violated the Trade Secret rights he has, then he as the holder of the Trade Secret or other party as the licensee can sue anyone who is intentionally and without the right of the Trade Secret. For example, according to article 4 of UURD "the owner of the Trade Secret has the right to use his own Trade Secret, give a license or prohibit other parties from using Trade Secrets or disclose the Trade Secret to third parties for commercial purposes". Regarding the article, the claim that we submitted can be a claim for compensation and / or termination of all acts. And different from other IPR claims, the lawsuit regarding the matter of the Trade Secret is submitted to the District Court.

In connection with the above, it must also be determined when actually an act is said to have violated the Trade Secret of another person or party. A person is considered to violate the trade secrets of another party if he obtains or controls the Trade Secret in a manner that is contrary to the applicable laws and regulations.

Besides that, there are also acts that are not considered as violations of the Trade Secret, namely if:

- The act of disclosing Trade Secrets or the use of Trade Secrets is based on the interests of defense and security, health or public safety.

Re-engineering of products produced from the use of other people's Trade Secrets is carried out solely for the benefit of further development of the product concerned. What is meant by reverse engineering in this case is an analysis and evaluation action to find out information about an existing technology.

\section{Trade Secret Elements}

1. information that is not known to the public in the field of technology and / or business

Not every information can be interpreted as a trade secret but must be information in the field of technology and or business. This means that the information on employee salaries and matters outside the business and / or technology fields is not the scope of the Trade Secret Law. While the scope of information technology can cover a very wide range, such as the method, composition, operation of the machine etc. Likewise, businesses also have very broad coverage among examples of unique marketing methods, customer lists, supplier lists etc.

2. has economic value because it is useful in business activities 
Economic value arises from information because in that information can be used in business activities so that other parties if they know the information can use it for business activities or increase business activities of competitors. This economic value is often identified with competitive power.

3. kept confidential by the owner of the trade secret.

Although an information has fulfilled an element of information that is not known to the public in the field of technology and / or business and has economic value because it is useful in business activities, it is not enough to make an information protected by the Trade Secret Law. trade secret. These steps must be appropriate and appropriate as stated in article 3 of the Trade Secret Law that there should be appropriate efforts. The Trade Secret Law itself does not regulate in detail about these methods. The author believes that there are at least 2 ways outlined in the protection of trade secrets:

1. Protection efforts from parties outside the company.

2. Protection efforts from parties within the company.

The above must be done because remembering the occurrence of violations of the right to trade secrets does not only occur because of outside parties who are interested but also internal parties such as employees for the purpose of making similar business by utilizing the trade secrets of the company where he works. These two things are not closed, therefore they need to be anticipated so that they do not happen to the disadvantaged parties.

In more detail the two protection measures by the owner can be implemented including the following:

1. Make a work contract in which detailed trade secret clauses contain what is treated as a trade secret for the company.

2. Make company regulations which contain trade secrets.

3. Provide a password on the company's online account or company computer.

4. Providing writing is prohibited from entering the production room.

5. Divide the employee's work section.

6. etc.

If the three elements have been fulfilled, without registration of trade secrets, they have received legal protection with the Trade Secret Law. That means that every business actor both small, medium and large businesses that have fulfilled the above elements have obtained legal protection.

Actually, in Intellectual Property Rights this forces each party to be innovative and creative. So that everyone can maximize their Intellectual Property.

\section{B. CONCLUSION}

Trade Secret is information that is not known by the public in the field of technology and / or business, has economic value because it is useful in business activities, and is kept confidential by the owner of the Trade Secret.

In the realm of IPR, basically the protection is based on the recognition of the right to wealth and the right to 
enjoy that wealth within a certain time. This means that during certain times the owner or right holder of IPR can allow or prohibit to know or disseminate information (Trade Secrets).

If someone feels the other party has violated the trade secret rights he has, then he as the holder of the Trade Secret or other party as the licensee can sue anyone who intentionally and without the right of the Trade Secret, then we can file a claim to the District Court. The lawsuit that we submit can be a compensation claim and / or termination of all actions. Besides that, other efforts can also be taken, namely through dispute resolution through Arbitration or Alternative Dispute Resolution (ADR).

\section{ACKNOWLEDGEMENT}

University Of Indonesia

University Of Mitra Indonesia

Telkom University

University Of Mellbourne

Saitama University

\section{REFERENCE (Based ISO 690 )}

[1] A. S. Putra And O. M. Febriani, "Knowledge Management Online Application In Pdam Lampung Province," In Prosiding International Conference On Information Technology And Business (Icitb), 2018, Pp. 181187.

[2] A. S. Putra, O. M. Febriani, And B. Bachry, "Implementasi Genetic Fuzzy System Untuk Mengidentifikasi Hasil Curian Kendaraan Bermotor Di Polda Lampung," J. Sist. Inf. Dan
Manaj. Basis Data, Vol. 1, No. 1, Pp. 21-30, 2018.

[3] O. M. Febriani And A. S. Putra, "Sistem Informasi Monitoring Inventori Barang Pada Balai Riset Standardisasi Industri Bandar Lampung," J. Inform., Vol. 13, No. 1, Pp. 90-98, 2014.

[4] Putra, Arie Setya. "2018 Artikel Struktur Data, Audit Dan Jaringan Komputer." (2018).

[5] Putra, A. S. (2018, July 17). Paperplain Fundamental Create Application With Borland Delphi 7.0 University Of Mitra Indonesia. Retrieved From Osf.Io/Pbrn9.

\section{E. REFERENCE (Based APA )}

Putra, A. S., Aryanti, D. R., \& Hartati, I. (2018, November). Metode SAW (Simple Additive Weighting) sebagai Sistem Pendukung Keputusan Guru Berprestasi (Studi Kasus: SMK Global Surya). In Prosiding Seminar Nasional Darmajaya (Vol. 1, No. 1, pp. 85-97).

Sari, D. P., Febriani, O. M., \& Putra, A. S. (2018, November). Perancangan Sistem Informasi SDM Berprestasi pada SD Global Surya. In Prosiding Seminar Nasional Darmajaya (Vol. 1, No. 1, pp. 289-294).

Putra, A. S. (2018). Paperplain: Execution Fundamental Create Application With Borland Delphi 7.0 University Of Mitra Indonesia.

Putra, A. S., Sukri, H., \& Zuhri, K. Sistem Monitoring Realtime Jaringan Irigasi Desa (JIDES) Dengan Konsep Jaringan Sensor Nirkabel. IJEIS 
(Indonesian Journal of Electronics and Instrumentation Systems), 8(2), 221232.

Darmawan, A., Yuliawati, D., Marcella, O., \& Firmandala, R. (2016). Sistem Absensi dan Pelaporan Berbasis Fingerprint dan SMS Gateway. EXPLORE, 7(1).

Febriani, O. M., Wahyuni, T., \& Yusuf, S. (2017). DESIGN OF WEBSITE-BASED INFORMATION SYSTEM FOR EDOCUMENT ADMINISTRASI IN THE COMMUNITY SERVICE UNIT (A Case Study at Rajabasa District). INTERNATIONAL JOURNAL OF COMPUTERS \& TECHNOLOGY, 16(7), 7010-7020.

Febriani, O. M., \& Wahyuni, T. (2017, October). PERANCANGAN SISTEM E-DOCUMENT ADMINISTRASI LOGBOOK PENELITIAN PADA UNIT LAYANAN DI BANDAR LAMPUNG. In Prosiding Seminar Nasional Darmajaya (Vol. 1, No. 1, pp. 187-194).

Febriani, O. M., \& Permadi, A. B. (2017). Implementasi Sistem Aplikasi Data Bimbingan dan Pelanggaran Siswa pada Sekolah Menengah Atas di Lampung Tengah dengan Metode Analisis dan Desain Sistem Terdistribusi (SSAD). EXPERT, 7(1).

Febriani, O. M., \& Ambarwati, L. (2015). PERANCANGAN APLIKASI PENGOLAHAN DATA PENJUALAN UKM KELANTING KHAS TELO DESA SIDOHARJO KECAMATAN JATI AGUNG KABUPATEN LAMPUNG
SELATAN. Jurnal Teknologi Informasi dan Bisnis Pengabdian Masyarakat Darmajaya, 1(1), 77-95.

Febriani, O. M. (2015). Rancang Bangun Aplikasi Ecommercemenggunakan Freewebstore pada UKM Kelanting di Desa Sidoharjo Lampung Selatan. Prosiding Sembistek 2014, 1(02), 446-458. 